\title{
Correction to: Biosecurity in pig farms: a review
}

Laura Valeria Alarcón ${ }^{1 *}$, Alberto Allepuz ${ }^{2,3}$ and Enric Mateu ${ }^{2,3}$ Correction to: Porcine Health Manag 19, $348(2021)$
https://doi.org/10.1186/s40813-020-00181-z

Following publication of the original article [1], we were notified of a mistake in the second author's name.

Originally published author name: Alberto Allepuz Alberto Corrected author name: Alberto Allepuz

The original article has been corrected.

\section{Author details}

${ }^{1}$ Facultad de Ciencias Veterinarias, Universidad Nacional de La Plata, Calle 60 y 118, La Plata, Buenos Aires, Argentina. ${ }^{2}$ Departament de Sanitat i Anatomia Animals, Facultat de Veterinària, Universitat Autònoma de Barcelona,

Travessera dels Turons s/n, 08193 Cerdanyola del Vallès, Barcelona, Spain.

${ }^{3}$ Centre de Recerca en Sanitat Animal (CreSA-IRTA-UAB), Campus UAB, 08193

Cerdanyola del Vallès, Barcelona, Spain.

Published online: 05 March 2021

\section{Reference}

1. Alarcón, et al. Biosecurity in pig farms: a review. Porcine Health Manag. 2021;19:348. https://doi.org/10.1186/s40813-020-00181-z.

The original article can be found online at https://doi.org/10.1186/s40813020-00181-z.

* Correspondence: Ivalarcon@hotmail.com

${ }^{1}$ Facultad de Ciencias Veterinarias, Universidad Nacional de La Plata, Calle 60

y 118, La Plata, Buenos Aires, Argentina

Full list of author information is available at the end of the article

(c) The Author(s). 2021 Open Access This article is licensed under a Creative Commons Attribution 4.0 International License, which permits use, sharing, adaptation, distribution and reproduction in any medium or format, as long as you give appropriate credit to the original author(s) and the source, provide a link to the Creative Commons licence, and indicate if changes were made. The images or other third party material in this article are included in the article's Creative Commons licence, unless indicated otherwise in a credit line to the material. If material is not included in the article's Creative Commons licence and your intended use is not permitted by statutory regulation or exceeds the permitted use, you will need to obtain permission directly from the copyright holder. To view a copy of this licence, visit http://creativecommons.org/licenses/by/4.0/. The Creative Commons Public Domain Dedication waiver (http://creativecommons.org/publicdomain/zero/1.0/) applies to the data made available in this article, unless otherwise stated in a credit line to the data. 